\title{
Within and Between-Tree Variation in Growth Ring Width of Pinus oocarpa Wood
}

\author{
Edwin Hara ${ }^{1}{ }^{2 *}$, Lusayo Mwabumba ${ }^{1}$ and Edward Missanjo ${ }^{2}$ \\ ${ }^{1}$ Department of Forestry, Faculty of Environmental Sciences, Mzuzu University, Private Bag 201, Luwinga, Mzuzu 2, Malawi \\ ${ }^{2}$ Department of Forestry, Malawi College of Forestry and Wildlife, Private Bag 6, Dedza, Malawi
}

Submission: June 11, 2018; Published: July 05, 2018

*Corresponding author: Edward Missanjo, Department of Forestry, Faculty of Environmental Sciences, Mzuzu University, Private Bag 201, Luwinga, Mzuzu 2, Malawi, Email: edward.em2@gmail.com

\begin{abstract}
Variation in growth ring width of 25-years-old Pinus oocarpa trees planted in central Malawi was investigated. A total of 30 discs were collected from six trees at breast height (1.3m from the ground level), 25\%, 50\%, $75 \%$ and $90 \%$ stem height. The estimated mean growth ring width was $5.98 \pm 0.15 \mathrm{~mm}$. The boundary between juvenile and mature wood was marked on ring number 8 from the pith. Growth ring width significantly $(\mathrm{P}<0.001)$ decreased from pith to bark and significantly $(\mathrm{P}<0.001)$ decreased from butt upwards. However, there were no statistical significant $(\mathrm{P}>0.05)$ differences in growth ring width in mature wood at different stem heights and radial position. Growth ring width had a significant $(\mathrm{P}<0.001)$ linear relationship with early wood width in both juvenile and mature wood. However, the relationship was stronger in juvenile wood $(\mathrm{r}=0.87)$ than in mature wood $(\mathrm{r}=0.77)$. There was a significant $(\mathrm{P}<0.001)$ negative relationship between growth ring width and latewood percentage in juvenile wood and no relationship was established in mature wood. In conclusion, the present study provides initial information for development of successful and appropriate tree breeding programme and wood utilization of $P$. oocarpa in Malawi and within the region.
\end{abstract}

Keywords: Pinus oocarpa; Growth Ring Width; Juvenile Wood; Mature Wood; Wood Utilization

\section{Introduction}

Pinus oocarpa Schiede ex Schltdl is a closed-cone pine native to Mexico and Central America [1]. It is one of the most common commercial timber species in countries within the tropics. The species grows at 350 to $2500 \mathrm{~m}$ above sea level but it grows best at 1200 to $1800 \mathrm{~m}$ with annual rainfall above $1200 \mathrm{~mm}$ [2]. $P$. oocarpa grows in different soil types however; it does much better in light, sandy clay soils with acidity of $\mathrm{pH} 4.0$ to 6.5. The species grows up to 20 to $35 \mathrm{~m}$ in height and 45 to $80 \mathrm{~cm}$ diameter at breast height (dbh) [3]. In the tropics the species is common in countries such as Kenya, Malawi, South Africa, Tanzania, Zambia and Zimbabwe [1].

Pinus oocarpa is one of major important exotic tree species in Malawi. It is well known for its fast growth rate and its high resistance to fire damage $[1,3]$. The species provide wood that is easy to work with machine and hand. It is also essentially used for resin production, packing boxes, plywood, fuel wood, construction timber as well as kindling [1]. In Malawi, P. oocarpa was introduced in 1950's mainly for timber production. However, in order to effectively utilize its wood, knowledge of wood properties is prerequisite. One such important property is growth ring width. According to Gogoi et al. [4], growth ring width is vital in tree growth and its reaction to climate change. It is for this reason that growth ring width forms a basis of the study of wood anatomy, dendroclimatology, dendrochronology and dendroecology [5]. Growth ring width is also important in the management of forest and manufacturing of wood products. This is so because growth ring width is strongly correlated with wood strength properties and tree diameter growth [6,7]. This means that information on growth ring width variation is important in forest management and wood utilization, since it can facilitate tree growth and quality of wood [8].

Regardless of these particulars, there is no information on within tree variation in growth ring width of Pinus oocarpa in Malawi. Differences in growth ring width are reported to be due to specific environmental factors, forest management practices and within controlled genetic factors [7]. In addition, lack of information on wood properties like growth ring width in Malawi has affected wood processing industries to match wood to specific purposes on the basis of their properties. This has eventually affected quality of infrastructure in construction industry. Inadequate knowledge in wood properties has also affected prices of timber on the market. The present trend on timber selling in Malawi is that all soft wood timber sale at the same price without considering their differences in wood properties. This may have negatively affected institutions involved in timber business who may have been undercharging their products by not considering wood properties. 
In terms of tree improvement, most tree breeding programmes consider volume production, adaptability, growth, form, and disease resistance as criteria for success. However, wood properties need to be taken into account [9]. This is imperative because it ensures trees of high volume production with desired properties. This is possible because genetic improvements of wood properties have high heritability than other characteristics and as such it is easy to incorporate them in breeding programmes. Although Pinus oocarpa is among the most important pine species that grows fast in Malawi, there is no detailed information on growth ring width. Few studies have been conducted on growth ring width pattern and variation in P. patula [10] and P. kesiya [7] of Malawi, and no studies have been conducted on growth ring width pattern and variation in P. oocarpa.

Therefore, the present study was carried out to investigate the within and between tree variation in growth ring width, to demarcate boundary between juvenile wood and mature wood and to establish relationships between growth ring width with earlywood and latewood percentage in P. oocarpa trees planted in central Malawi. Information gained provide basis for development of successful and appropriate tree breeding programme and wood utilization of P. oocarpa planted in Malawi and within the region.

\section{Materials and Methods}

\section{Study Site}

The study was conducted at Chongoni Timber Plantation (CTP) in Dedza, Central Malawi. The plantation is located within Chongoni Forest Reserve (140 22' S, 34020' E) approximately $85 \mathrm{~km}$ southeast of Lilongwe the capital. CTP covers an estimated area of 5270 ha composing mostly P. patula, P. kesiya and P. oocarpa. The reserve lies on altitude range $1570-1690 \mathrm{~m}$ above the sea level. It receives a mean annual rainfall in the range of about $1200 \mathrm{~mm}$ to $1800 \mathrm{~mm}$ with a mean annual temperatures ranging from $7 \mathrm{oC}$ to $25 \mathrm{oC}$. The forest is characterised by ferruginous and humic ferrallitic soils [11].

\section{Plant Material and Sampling}

Table 1: Diameter at breast height $(\mathrm{DBH})$ and total stem height $(\mathrm{Ht})$ of sampled P. oocarpa trees

\begin{tabular}{|c|c|c|}
\hline Tree No. & DBH $(\mathrm{cm})$ & Ht $(\mathrm{m})$ \\
\hline 1 & 32 & 20.4 \\
\hline 2 & 40 & 22.4 \\
\hline 3 & 28 & 17.9 \\
\hline 4 & 28 & 22.1 \\
\hline 5 & 26 & 21.2 \\
\hline 6 & 42 & 23.3 \\
\hline
\end{tabular}

$\mathrm{DBH}$, diameter at breast height (1.3m above the ground); $\mathrm{Ht}$, total stem height

The material for the study was collected from compartment no. 3 in Chongoni Forest Plantation. Establishment of the compartment and silvicultural operations are well explained in our previous study [12]. At the age of 25 years (in March 2017) six trees were randomly selected and harvested. The estimated rotational age of Pinus oocarpa is 25-30 years. The trees were chosen based on straightness. Felling of trees was done by cutting the stems at $15 \mathrm{~cm}$ above the ground. Total stem height and diameter at breast height (1.3m above the ground) for each tree were measured before felling (Table 1). Cross-sectional discs (Figure 1) of $5 \mathrm{~cm}$ thickness were cut from each felled tree at breast height ( $1.3 \mathrm{~m}$ from the ground level), 25\%, 50\%, 75\% and $90 \%$ stem height.

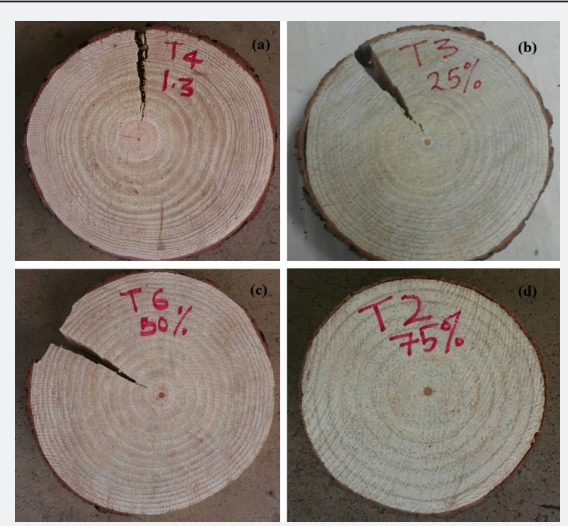

Figure 1: Cross-sectional discs obtained from P. oocarpa (at breast height, tree no. $4(\mathrm{a})$; at $25 \%$ stem height, tree no. 3 (b); at $50 \%$ stem height, tree no. 6 (c); at $75 \%$ stem height, tree no. 2 (d)).

\section{Sample Processing and Measurement}

The cross-sectional discs were each smothered to the end grain by a sand paper. Radial strips from the north side of each disc were sawn from bark to pith and then air-dried. Growth ring widths and earlywood widths were measured from pith to bark using image analysis. Latewood percentage was calculated as: Growth ring width minus earlywood width divide by growth ring width multiply by 100 .

\section{Statistical Analysis}

Data on latewood percentage, growth ring width, and earlywood width were tested for homogeneity and normality in Gen Stat 18 [13]. However, no data transformation was deemed necessary. Graphic method using latewood percentages was used to determine the juvenile and mature wood boundary. In this method latewood percentages were logarithmically regressed to produce a model. Juvenile wood was defined as a zone where latewood percentage increased rapidly with ring number, while mature wood was defined as a zone where latewood percentage gradually increased or was stable. The point at which latewood percentage increment began to stabilize was treated as the boundary between juvenile wood and mature wood.

Analysis of Variance (ANOVA) for growth ring width was done in accordance to the model presented in Table 2 to test the significance of zone (mature/juvenile wood), position, height level and tree effects. Trees were considered as random effects, while the other sources of variation were considered as fixed effects. Fischer's least significant difference (LSD) at the 0.05 significance 
level was used to separate means. Furthermore, variance components for the sources of variation were also estimated. ANOVA was performed using GenStat 18 [13]. The relationship between growth ring width with earlywood and latewood percentage in juvenile and mature wood was determined using regression analysis.

Table 2: Model used in the analysis of variance.

\begin{tabular}{|c|c|}
\hline No. & Source of Variation \\
\hline 1 & Zone (juvenile/mature wood) $(\mathrm{Z})$ \\
\hline 2 & Tree $(\mathrm{T})$ \\
\hline 3 & Height level (L) \\
\hline 4 & $\mathrm{~L} \times \mathrm{Z}$ \\
\hline 5 & $\mathrm{~L} \times \mathrm{T}$ \\
\hline 6 & Radial position (P) \\
\hline $7^{*}$ & $\mathrm{P} \times \mathrm{Z}$ \\
\hline 8 & $\mathrm{P} \times \mathrm{T}$ \\
\hline 9 & $\mathrm{P} \times \mathrm{L}$ \\
\hline $10^{*}$ & $\mathrm{P} \times \mathrm{L} \times \mathrm{Z}$ \\
\hline 11 & $\mathrm{R} / \mathrm{P} / \mathrm{L} / \mathrm{T} / \mathrm{Z}$ \\
\hline
\end{tabular}

Note: *Source of variations were removed from the final analysis because their contribution to the total variance were negligible.

\section{Results and Discussion}

\section{Juvenile and Mature Wood Boundary}

The demarcation of the boundary between juvenile wood and mature wood is essential because it helps optimize timber utilization, quality and value of final products [7]. Different methods have been used to determine the juvenile and mature wood boundary. Adamopoulos \& Voulgaridis [14] used simple graphic method linear, while Gogoi et al. [4] and Sharma et al. [15] used non-linear and polynomial models of regression in determining the boundary. However, for the purposes of the present research, simple graphic method (logarithmic regression analysis) was used. A summary of results on the juvenile and mature wood boundary are presented in Figure 2. Latewood percentages were regressed logarithmically. Figure 2 shows that the radial pattern of latewood percentage could be calculated using the function: $\mathrm{Y}=8.6916 \ln (\mathrm{x})+24.678$. Then, latewood percentage increment for each ring number was estimated and plotted (Figure 2 secondary vertical axis). The results in Figure 2 revealed that latewood percentage increment decreased with increase in ring number thus from pith to bark. The percentages sharply decreased near the pith and started stabilizing at around ring number 8 , when the latewood percentage increment decreased to $1 \%$. Beyond ring number 8 and near the bark there was a gradual decrease and stable pattern in latewood percentage. Therefore, ring number 8 from the pith can be regarded as the juvenile and mature wood boundary. On that account, juvenile wood would be represented by rings $1-8$, while mature wood would be represented by rings 8 to the bark. The sharp fall of latewood in juvenile wood may be attributed to the fact that during early stages of growth, a tree is more actively growing and needs high proportion of early wood for conduction. In contrast, in mature wood (ring 8 to bark), the tree is growing slowly and does not need a lot of conduction [2,4]. In terms of tree improvement efforts, selection in tree breeding programmes would be more effective by considering outer wood than inner wood. Therefore, this should be taken into account when planning for forest management and product manufacturing using $P$. oocarpa.

The present results are in contrast with those in literature $[4,7,16,17]$. Gogoi et al. [4] and Missanjo \& Matsumura [7] reported ring number 10 from the pith as the juvenile and mature wood boundary in P. kesiya. Zhu et al. [16] observed ring number 15 from the pith as boundary in Japanese larch (Larix kaempferi), while Ladrach [17] reported ring number 6 from pith as boundary between juvenile wood and mature wood in $P$. oocarpa. This means that juvenile/mature boundary is not constant but varies with species and depends on site conditions [18].

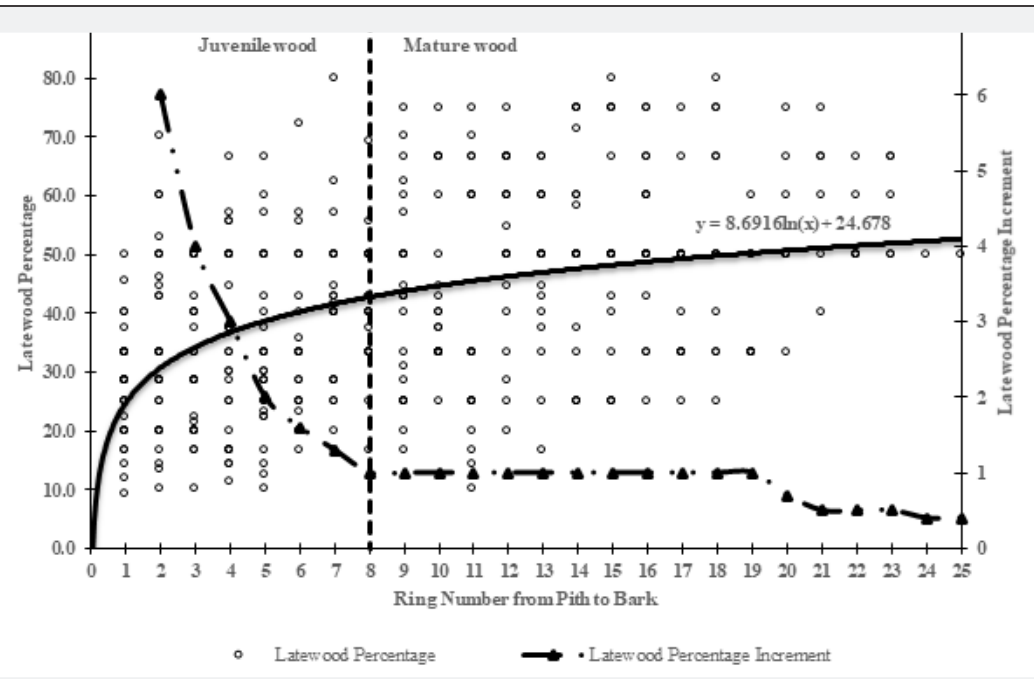

Figure 2: Variation of latewood percentage of P. oocarpa from pith to bark and the boundary between juvenile wood and mature wood. 
Variation in growth ring width within and between trees

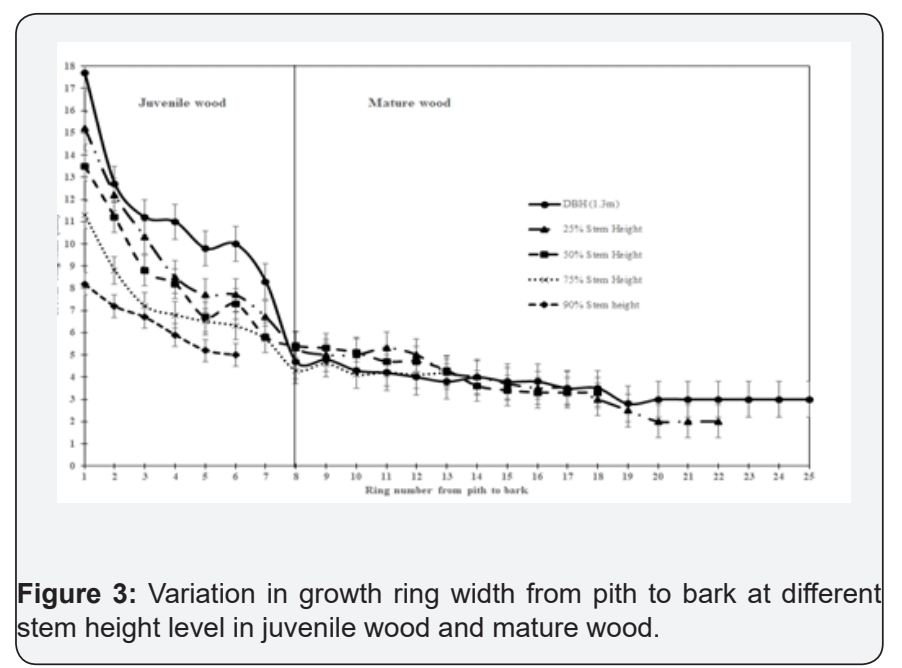

Table 3: Mean growth ring width values per zone (juvenile/mature wood), stem height level and tree of $P$. Oocarpa.

\begin{tabular}{|c|c|}
\hline Category & Growth ring width $(\mathrm{mm})$ \\
\hline \multicolumn{2}{|l|}{ Tree no. } \\
\hline 1 & $5.80 \pm 0.22^{b}$ \\
\hline 2 & $8.68 \pm 0.22^{\mathrm{a}}$ \\
\hline 3 & $5.31 \pm 0.22^{b}$ \\
\hline 4 & $5.09 \pm 0.22^{\mathrm{b}}$ \\
\hline 5 & $5.28 \pm 0.23^{b}$ \\
\hline 6 & $9.08 \pm 0.21^{\mathrm{a}}$ \\
\hline \multicolumn{2}{|l|}{ Stem height level } \\
\hline $1(\mathrm{dbh})$ & $7.33 \pm 0.16^{\mathrm{a}}$ \\
\hline $2(25 \%)$ & $6.66 \pm 0.17^{\mathrm{ab}}$ \\
\hline $3(50 \%)$ & $6.02 \pm 0.18^{b c}$ \\
\hline $4(75 \%)$ & $5.53 \pm 0.33^{c}$ \\
\hline $5(90 \%)$ & $3.43 \pm 0.33^{\mathrm{d}}$ \\
\hline \multicolumn{2}{|l|}{ Zone } \\
\hline Juvenile wood & $8.01 \pm 0.14^{\mathrm{a}}$ \\
\hline Mature wood & $5.42 \pm 0.12^{\mathrm{b}}$ \\
\hline Mean & $5.98 \pm 0.15$ \\
\hline
\end{tabular}

Mean values are followed by standard errors; Means with different superscript within a column and category are significantly different $(\mathrm{P}<0.001)$

Summary of the results on the variation of growth ring width within and between trees are presented in Figure 3 and Tables $3 \& 4$. Zone (juvenile/mature wood), tree-to-tree, radial position and stem height position significantly $(\mathrm{P}<0.001)$ influenced the growth ring width. Juvenile wood had a longer mean growth ring width than mature wood. Further, the results reveals that there were statistical significant $(\mathrm{P}<0.001)$ differences in growth ring width along the radius and among different stem height levels in juvenile wood. At first, the growth ring width near the pith was relatively wide and decreased rapidly during the early years of growth up to ring 8. They then almost levelled off to almost a constant up to the bark. Growth ring width also decreased from butt upwards. Genetic and environmental factors may be the cause of growth wing width decrease from pith to bark $[4,16]$. On the other hand, the increase in juvenile properties from the butt upwards may be due to auxin gradient theory [19]. The theory states that, the endogenous auxin that arises in the growing shoots (apical region) stirs xylem differentiation and cambial division. As a result, this causes great production of early wood near the crown contributing portentously to reduced growth ring width at the top. On the other hand, radial position and stem height level had no effect on the growth ring width in mature wood (Figure $3)$. Tree was the highly significant source of variation (Table 4), explaining $22.8 \%$ of total variation. Tree contributed greatly to variation possibly because of differences in genotype of individual trees in the compartment such that some individuals responded well to environmental fluctuations than others.

Table 4: Variance components for growth ring width of $P$. Oocarpa.

\begin{tabular}{|c|c|c|c|}
\hline \multirow{2}{*}{$\begin{array}{c}\text { Source of } \\
\text { variation }\end{array}$} & df & \multicolumn{2}{|c|}{ Growth ring width } \\
\cline { 2 - 4 } & 1 & $<0.001$ & 12.7 \\
\hline $\begin{array}{c}\text { Zone (juvenile/ } \\
\text { mature wood) } \\
(\mathrm{Z})\end{array}$ & 5 & $<0.001$ & 22.8 \\
\hline Tree (T) & 4 & $<0.001$ & 16.6 \\
\hline Height level (L) & 3 & $<0.001$ & 3.5 \\
\hline $\mathrm{L} \times \mathrm{Z}$ & 20 & $<0.001$ & 3.9 \\
\hline $\mathrm{L} \times \mathrm{T}$ & 24 & $<0.001$ & 10.8 \\
\hline $\begin{array}{c}\text { Ring position } \\
(\mathrm{P})\end{array}$ & 105 & 0.185 & 9.1 \\
\hline $\mathrm{P} \times \mathrm{T}$ & 52 & 0.447 & 4.0 \\
\hline $\mathrm{P} \times \mathrm{L}$ & 222 & & 16.6 \\
\hline $\mathrm{R} / \mathrm{P} / \mathrm{L} / \mathrm{T} / \mathrm{Z}$ & & & \\
\hline
\end{tabular}

$d f$ degree of freedom, Var variance (\%)

\section{Growth ring width relationship with earlywood and latewood percentage}

A summary of results on growth ring width relationship with earlywood width and latewood percentage in juvenile and mature wood are presented in Figures $4 \& 5$, respectively. Figure 4 indicates that there was a significant $(\mathrm{P}<0.001)$ linear relationship between growth ring width and earlywood width in both juvenile wood and mature wood. However, there was a strong linear relationship in juvenile wood $(\mathrm{r}=0.87)$ than in mature wood $(\mathrm{r}=0.77)$. This indicates that growth ring width was increasing with an increase in the proportion of early wood width on every ring both in juvenile and mature wood. However, the increase was higher in juvenile wood than in mature wood. Unlike in mature wood, the higher proportion of early wood in juvenile wood may be attributed to the fact during juvenile stage; earlywood tissue provides a lot of conduction function for water and essential 
nutrients [19]. The present results are in agreement to those reported by other researchers [16]. Zhu et al. [16] observed that growth ring width in juvenile wood was significantly correlated with earlywood width but weakly correlated with latewood width.
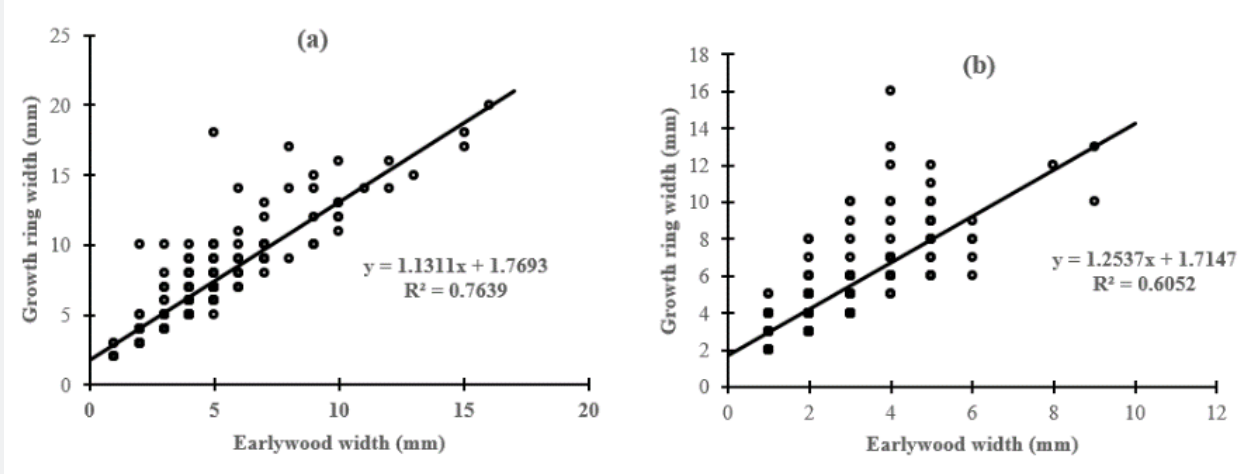

Figure 4: The relationship between growth ring width and earlywood in juvenile wood (a), and in mature wood (b).
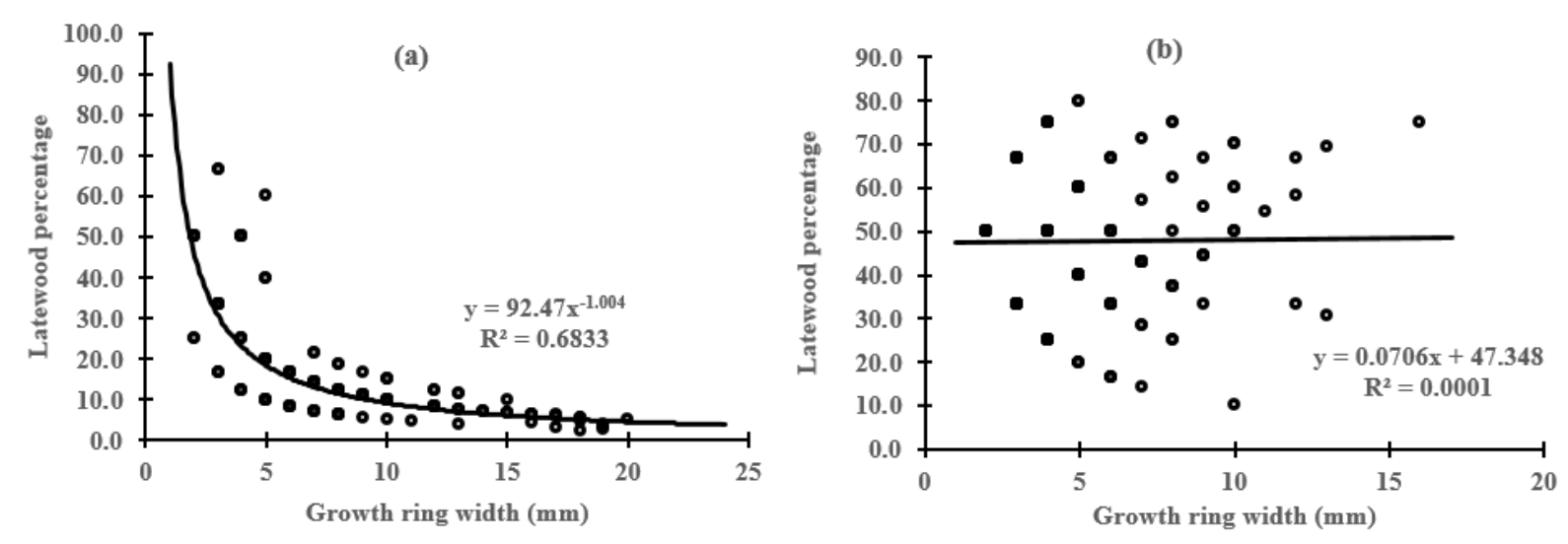

Figure 5: The relationship between growth ring width and latewood percentage in juvenile wood (a), and in mature wood (b).

Figure 5 shows that there was a significant $(\mathrm{r}=0.83$; $\mathrm{P}<0.001)$ negative relationship between growth ring width and latewood percentage in juvenile wood. On the other hand, there was no relationship $(\mathrm{r}=0.01 ; \mathrm{P}>0.05)$ between growth ring width and latewood percentage in mature wood. The relationship between growth ring width with earlywood and latewood have a strong effect on strength properties and wood performance in structural applications $[10,19]$. According to Kamala et al. [10] wide growth rings with a low proportion of latewood may be of concern in products where strength is important. This is the case because wood strength increases with an increase in latewood proportion in a growth ring [19]. However, the present study indicates no relationship between growth ring width and latewood proportion in mature wood (Figure 5). This suggests that improving growth ring width in mature wood of $P$. oocarpa would have no effect in wood strength. However, further research is required to confirm the relationship between growth ring width and wood strength in P. oocarpa planted in Malawi.

\section{Conclusion}

The present study has revealed that the boundary between juvenile and mature wood falls on ring number 8 from pith. Therefore, rings 1-8 is treated as juvenile wood while beyond ring 8 to the bark is treated as mature wood. Juvenile wood had a significant longer mean growth ring width than mature wood. Growth ring width significantly decreased from pith to bark and significantly decreased from butt upwards. However, there were no statistical significant differences in growth ring width in mature wood at different stem heights and radial position. Growth ring width had a significant linear relationship with early wood width in both juvenile and mature wood. However, the relationship was stronger in juvenile than in mature wood. There was a significant negative relationship between growth ring width and latewood percentage in juvenile wood and no relationship was established in mature wood. Basing on the above conclusions, this study is important for development of successful and appropriate tree 
breeding programmes and wood utilization of $P$. oocarpa in Malawi.

\section{Conflict of Interests}

The authors declare that there is no conflict of interests in any form regarding the publication of this article titled "Within and Between-Tree Variation in Growth Ring Width of Pinus oocarpa Wood."

\section{References}

1. Ndema A, Missanjo E (2015) Tree Growth Response of Pinus oocarpa Along Different Altitudes in Dedza Mountain Forest Plantation. Agriculture, Forestry and Fisheries 4(1): $24-28$.

2. Braga EP, Zenni RD, Hay JD (2014) A New Invasive Species in South America: Pinus oocarpa Schiede ex Schltdl. BioInvasions Records 3(3): 207-211.

3. Dvorak W (2002) Pinus oocarpa Schiede ex Schltdl. In: Vozzo J (ed), Tropical Tree Seed Manual. U.S. Department of Agriculture, Forest Service, USA, pp. 899.

4. Gogoi BR, Sharma M, Sharma CL (2014) Ring width variations of Khasi pine (Pinus kesiya Royle ex Gordon) at breast height. Journal of the Indian Academy of Wood Science 11(1): 87-92.

5. Sousa VB, Cardoso S, Quilho T, Pereira H (2012) Growth rate and ring width variability of teak, Techna grandis (Verbenaceae) in an unmanaged forest in East Timor. International Journal of Tropical Biology and Conservation 60(1): 483-494.

6. Alteyrac J, Cloutier A, Ung CH, Zhang SY (2006) Mechanical properties in relation to selected wood characteristics of black spruce. Wood and Fiber Science 38(2): 229-237.

7. Missanjo E, Matsumura J (2016) Radial Variation in Tracheid Length and Growth Ring Width of Pinus kesiya Royle ex Gordon in Malawi. International Journal of Research in Agriculture and Forestry 3(1): 1321.

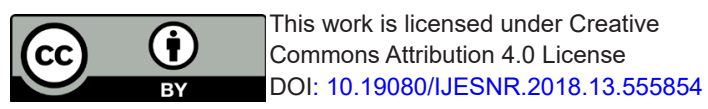

8. Sharma CL, Sharma M, Carter MJ (2013) Radial variation in fibre length and wood density of Melanorrhoea usitata Wall. The Indian Journal of Forestry 139(6): 518-520.

9. Hernandez RE, Koubaa A, Beaudoin M, Fortin Y (1998) Selected mechanical properties of fast-growing poplar hybrid clones. Wood Fiber Science 30(2): 138-147.

10. Kamala FD, Sakagami H, Oda K, Matsumura J (2013) Wood Density and Growth Ring Structure of Pinus patula Planted in Malawi, Africa. IAWA Journal 34(1): 61-70.

11. Hardcastle PD (1978) A preliminary Silvicultural classification of Malawi. Forest Research institute of Malawi, Zomba, Malawi.

12. Malata H, Ngulube ES, Missanjo E (2017) Specific Site Stem Volume Models for Pinus patula and Pinus oocarpa. International Journal of Forestry Research.

13.VSN International (2015) Genstat for Windows $\left(18^{\text {th }}\right.$ edn.), VSN International, Hemel Hempstead, UK.

14. Adamopoulos S, Voulgaridis E (2002) Within tree variation in growth rate and cell dimensions in the wood of black locust (Robinia pseudoacacia). IAWA Journal 23(2): 191-199.

15. Sharma CL, Sharma M, Jamir L (2014) Radial variation in wood properties of plantation grown Terminalia myriocarpa Heurck and Muell-Arg in Nagaland, India. Research Journal of Recent Sciences 3(ISC-2013): 9 -14.

16. Zhu J, Nakano T, Hirakawa Y (2000) Effect of radial growth rate on selected indices for juvenile and mature wood of Japanese larch. Journal of Wood Science 46(6): 417-422.

17. Ladrach WE (1986) Control of wood properties in plantations. IUFRO Congr Ljubjana, Yugoslavia, pp. 369-381.

18. Zobel BJ, Sprague JR (1998) Juvenile Wood in Forest Trees. SpringerVerlag, Berlin Heidelberg.

19. Izekor DN, Fuwape JA, Oluyege AO (2010) Effects of density on variations in the mechanical properties of plantation grown Tectona grandis wood. Archives of Applied Science Research 2(6): 113-120.

\section{Your next submission with Juniper Publishers will reach you the below assets}

- Quality Editorial service

- Swift Peer Review

- Reprints availability

- E-prints Service

- Manuscript Podcast for convenient understanding

- Global attainment for your research

- Manuscript accessibility in different formats

( Pdf, E-pub, Full Text, Audio)

- Unceasing customer service

Track the below URL for one-step submission https://juniperpublishers.com/online-submission.php 